\title{
HYPOGLYCEMIC ACTIVITY OF 10 MEDICINAL PLANTS EXTRACT IN GLUCOSE INDUCED MICE
}

\author{
AHMAD MUHTADI ${ }^{1 *}$, YOLA IRENKA ${ }^{1}$, WULAN CHANDRA AYU ${ }^{1}$, RINI HENDRIANI ${ }^{1}$, ADE ZUHROTUN $^{2}$
}

${ }^{1}$ Department of Pharmacology and Clinical Pharmacy, Faculty of Pharmacy, Universitas Padjadjaran, Indonesia. ${ }^{2}$ Department of Biology Pharmacy, Faculty of Pharmacy, Universitas Padjadjaran, Indonesia. Email: a.muhtadi@unpad.ac.id

Received: 04 November 2016, Revised and Accepted: 24 January 2017

ABSTRACT

Objective: To evaluate and compare the hypoglycemic activity of 10 medicinal plants extract that is used empirically to treat hyperglycemia in Indonesia, to determine plant with the most potential as a hypoglycemic agent.

Methods: Activity test was conducted in Swiss Webster glucose-induced mice with glucose tolerance test. The ethanolic extracts of Mangifera indica L. leaves, Persea americana Mill. leaves, Acorus calamus L. rhizome, Phyllanthus niruri L. herb, Syzygium cumini (L.) skeels bark, Zingiber officinale Roscoe rhizome, Moringa oleifera Lam. leaves, Tamarindus indica L. seed, Momordica charantia L. fruits, and Azadirachta indica A. juss leaves, which were given orally at the same dose of $300 \mathrm{mg} / \mathrm{kg}$ bw. The blood samples were used for determination of glucose level examination using a glucose meter and test strips (Accu-Chek).

Results: The ethanolic extract of $M$. indica L. leaves has the best activity in reduction of blood glucose level in mice, followed by $Z$. officinale Roscoe rhizome, A. calamus L. rhizome, T. indica L. seed., M. charantia L. fruit., S. cumini (L.) skeels bark, P. niruri L. herb., P. americana Mill. leaves, and A. indica A. juss leaves.

Conclusion: Results of this study suggest the potential use of $M$. indica L. leaves extract in the therapy of hyperglycemia.

Keywords: Hypoglycemic, Medicinal plants, Mangifera indica L. leaves, Glucose tolerance test.

(C) 2017 The Authors. Published by Innovare Academic Sciences Pvt Ltd. This is an open access article under the CC BY license (http://creativecommons. org/licenses/by/4. 0/) DOI: http://dx.doi.org/10.22159/ajpcr.2017.v10s2.19473

\section{INTRODUCTION}

Diabetes mellitus (DM) is a metabolic disease characterized by hyperglycemia, caused by lack of insulin production, insulin resistance, or both. It is generally classified into type 1 and 2 diabetes. Type 1 diabetes is insulin dependent for life (5-10\%), occurs because of $\beta$ pancreas cells damage. While type 2 diabetes (90-95\%) occurs due to insulin resistance, insufficient production of insulin, or both [1]. This disease can also cause chronic complications include abnormalities in microvascular and macrovascular [2]

In Indonesia, the prevalence of diabetes in adulthood, 20-79 years, was $5.8 \%$ of the 9 million total diabetic cases and 4.8 million undiagnosed diabetic cases in 2014 [3]. Oral hypoglycemic drugs, such as biguanide, sulfonylurea, and tiazolidinedionas, are used clinically in the treatment of type 2 diabetes, but it may cause adverse effects and become ineffective in long diabetic treatment. The World Health Organization recommended the use of traditional medicine with basic material of plants for diabetes treatment [4]. Alternative measures using herbal medicine agents may also be considered to achieve lower blood glucose levels, with minimal side effects and low cost [5]. As a rich biodiversity country, Indonesia has 30.000 flowering plants species [6], about 7000 of these species are recognized as medicinal plants [7], 950 species are discovered to have pharmacological properties, 283 species are registered, being cultivated and used by industries [8] and another species directly harvested from forest as raw material [9]. Many plants have potential as an antidiabetic agent that can be proven through ethnobotany information report [10]. The aim of this study is to evaluate and compare the hypoglycemic activity of 10 plants, which are used empirically to treat diabetes in Indonesia. The screened plant parts were mango (Mangifera indica L.) leaves [11], avocado (Persea americana Mill.) leaves [12], meniran (Phyllanthus niruri L.) herb [13], Kelor (Moringa oleifera Lam.) leaves [14], ginger (Zingiber officinale Roscoe) rhizome [15], jeringau (Acorus calamus L.) rhizome [16], jamblang (Syzygium cumini (L.) skeels leaves [17], asam jawa (Tamarindus indica L.) seed [18], pare (Momordica charantia L.) fruit [17], and Mimba (Azadirachta indica A. juss) leaves [19] which were given orally at the same doses $(300 \mathrm{mg} / \mathrm{kg} \mathrm{bw})$ in mice induced glucose.

\section{METHODS}

Plant materials

The plant materials were collected from several areas, $M$. indica $L$. leaves, $P$. americana Mill. leaves and $A$. calamus L. rhizome were collected from Lembang, West Java; P. niruri L. herb, S. cumini (L.) skeels bark, and $Z$. officinale Roscoe rhizome were collected from Subang, West Java; $M$. oleifera Lam. leaves were collected from Karanganyar, Center Java; $T$. indica L. seed were collected from Majalengka, West Java; M. charantia L. fruit were collected from Cimahi, West Java; and $A$. indica A. juss leaves were collected from Tawangmangu, Center Java. Those plants were authenticated at Jatinangor Herbarium, Plant Taxonomy Laboratory, Department of Biological Science, UNPAD.

\section{Plant extraction}

Plant materials were dried, grounded, extracted (by maceration method in $70 \%$ ethanol) and concentrated (using rotary evaporator under reduced pressure [Rotavapor, Buchi]). Extract was dissolved in $2 \%$ acacia gum propylene glycol alginate (PGA) to prepare doses and administered by oral gavage.

\section{Animal preparation}

The animal house ITB supplied male Swiss Webster mice, weighing 25-35 g. They were housed under standard laboratory condition at a room temperature of $22 \pm 3^{\circ} \mathrm{C}$ and relative humidity of $50-60 \%$, with $12 \mathrm{hrs}$ light and dark cycle. Food and water were provided ad libitum according to the laboratory standard. Ethical clearance for experimental animals using was obtained from Ethical Committee of Medical Faculty 
UNPAD with Ethical Approval No. 204/UN6.C1.3.2/KEPK/PN/2016 and 206/UN6.C1.3.2/KEPK/PN/2016.

\section{Hypoglycemic activity assay}

Oral glucose tolerance test was used to evaluate and compare the hypoglycemic activity of 10 plants ethanolic extract that was tested. Mice were divided into 12 groups ( 3 mice per group), previously been fasted for $18 \mathrm{hrs}$. Normal control group was given PGA 2\%. Negative control group was given PGA $2 \%$ and glucose $1 \mathrm{~g} / \mathrm{kg}$ bw. Test group was given PGA 2\%, glucose $1 \mathrm{~g} / \mathrm{kg}$ bw and plant extracts tested at an oral dose of $300 \mathrm{mg} / \mathrm{kg}$ bw. Blood sampling was performed at 30 minutes after given plant extract $(t=0)$, then at 30 minutes $(t=30), 60$ minutes $(t=60)$, 90 minutes $(\mathrm{t}=90)$, and 120 minutes $(\mathrm{t}=120)$ after administration of glucose, determination of glucose level using a glucose meter and strips test (Accu-Chek).

\section{RESULTS AND DISCUSSION}

The effect of ethanolic plants extract on blood glucose levels in glucoseinduced mice was presented by considering relative blood glucose (\%), as shown in Fig. 1 and Table 1. All tested plants extracts might lead the reduction of blood glucose levels at a dose of $300 \mathrm{mg} / \mathrm{kg} \mathrm{bw}$, which was related to the duration time of treatment.
As shown in Fig. 1, the negative control group had the highest relative blood glucose levels, indicating that induction method was worked by glucose administration. The relative blood glucose levels decreased in 60 minutes, indicating that the body released insulin hormone to break glucose as a homeostatic process.

Oral administration of 10 medicinal plants within ethanolic extract was performed at a dose of $300 \mathrm{mg} / \mathrm{kg}$, producing various outcomes of blood glucose levels. As shown in Table 1, the highest enhancement of glucose levels occurred at 30 minutes, which was shown in all tested samples $Z$. officinale Roscoe rhizome group was significantly different, compared to negative control, meaning that the extract has hypoglycemic activity better than others at that same period time. While at 60 and 90 minutes, all test groups were significantly different with negative control group.

This showed that the hypoglycemic activity of all tested extracts decreased the blood glucose levels of tested animals. At 120 minutes, all groups had the lowest relative blood glucose levels, compared to all interval times. In particular, $M$. indica L. leaves, P. americana Mill. leaves, $P$. niruri L. herb, Z. officinale Roscoe rhizome, A. calamus L. rhizome, $S$. cumini (L.) skeels bark, T. indica L. seed, and M. charantia L. fruit group had significantly differences, compared to negative control, indicating

Table 1: Hypoglycemic activity of ethanolic extract of 10 medicinal plants, where the blood sampling was performed at 30 minutes after given plant extract $(t=0)$, at 30 minutes $(t=30), 60$ minutes $(t=60), 90$ minutes $(t=90)$, and 120 minutes ( $t=120)$ after administration of glucose, determination of glucose level using glucose meter and strips test (Accu-Chek)

\begin{tabular}{|c|c|c|c|c|c|}
\hline \multirow[t]{3}{*}{ Group } & \multicolumn{5}{|c|}{ Relative blood glucose level (\%) } \\
\hline & \multicolumn{5}{|c|}{ Time (minute) mean \pm SD } \\
\hline & $\mathbf{0}$ & 30 & 60 & 90 & 120 \\
\hline Normal control & 100 & $101.11 \pm 9.20 *$ & $96.99 \pm 11.20^{*}$ & $93.87 \pm 11.58^{*}$ & $83.18 \pm 8.21^{*}$ \\
\hline Negative control & 100 & $206.76 \pm 7.33$ & $194.79 \pm 5.39$ & $177.53 \pm 12.76$ & $139.76 \pm 40.80$ \\
\hline Mangifera indica L. leaves & 100 & $125.53 \pm 13.33$ & $104.49 \pm 19.85^{*}$ & $89.20 \pm 20.39 *$ & $83.70 \pm 6.50 *$ \\
\hline Persea americana Mill. leaves & 100 & $164.2 \pm 17.81$ & $127.69 \pm 9.47 *$ & $93.01 \pm 3.12^{*}$ & $81.29 \pm 7.60^{*}$ \\
\hline Moringa oleifera Lam. leaves & 100 & $184.27 \pm 47.70$ & $154.28 \pm 31.72^{*}$ & $114.16 \pm 34.50^{*}$ & $87.27 \pm 28.02$ \\
\hline Zingiber officinale Roscoe rhizome & 100 & $120.06 \pm 7.88^{*}$ & $109.88 \pm 15.83 *$ & $93.50 \pm 21.16^{*}$ & $83.40 \pm 12.69 *$ \\
\hline Acorus calamus L. rhizome & 100 & $143.96 \pm 25.84$ & $99.76 \pm 5.30^{*}$ & $88.18 \pm 5.30^{*}$ & $80.35 \pm 4.23^{*}$ \\
\hline Syzygium cumini (L.) skeels bark & 100 & $145.22 \pm 41.46$ & $115.83 \pm 14.07^{*}$ & $88.13 \pm 15.28^{*}$ & $79.41 \pm 22.17^{*}$ \\
\hline Tamarindus indica L. seed & 100 & $156.40 \pm 29.83$ & $103.04 \pm 14.44^{*}$ & $95.42 \pm 22.39^{*}$ & $65.92 \pm 19.29 *$ \\
\hline Momordica charantia L. fruit & 100 & $144.76 \pm 27.02$ & $110.52 \pm 30.41^{*}$ & $93.57 \pm 16.08^{*}$ & $70.96 \pm 13.38 *$ \\
\hline Azadirachta indica A. juss leaves & 100 & $135.86 \pm 12.90$ & $127.47 \pm 16.26^{*}$ & $121.75 \pm 24.04$ & $89.90 \pm 10.08$ \\
\hline
\end{tabular}

*Significant compared with negative control $(\mathrm{p}<0.05)$

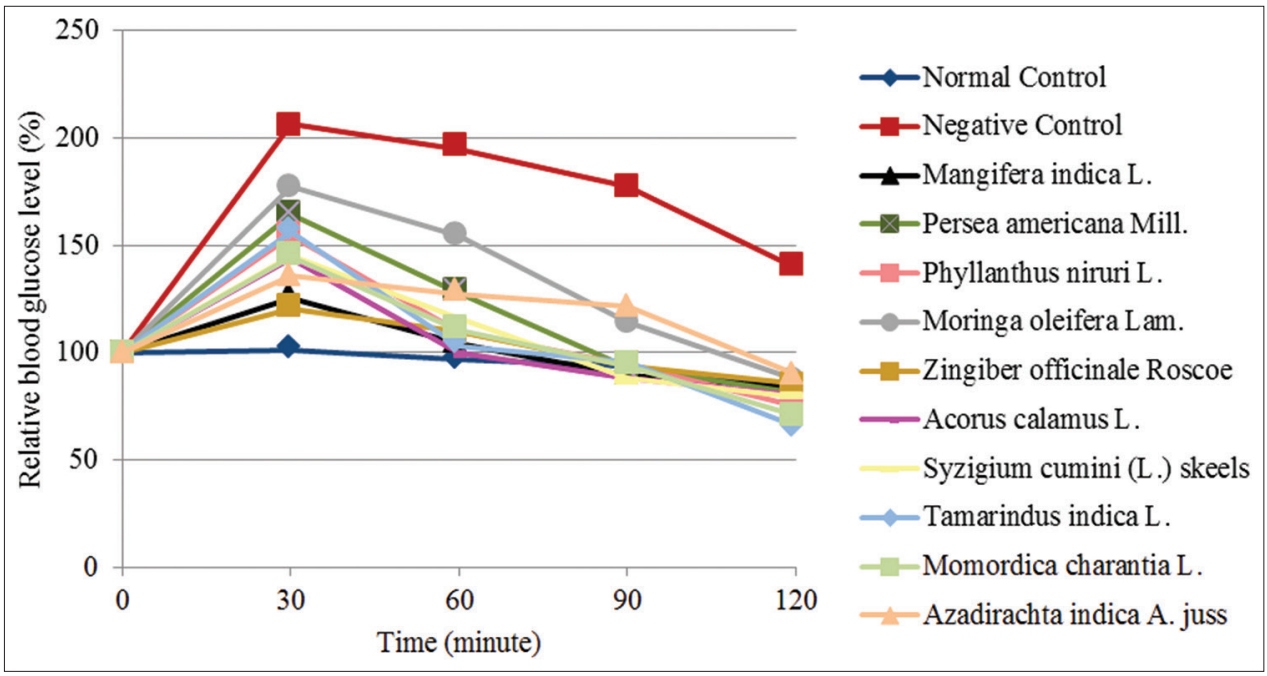

Fig. 1: Relative blood glucose level (\%) of 10 medicinal plants, which are often used as remedies for hyperglycemia in Indonesia. The ethanolic extract was tested for their hypoglycemic activity using glucose tolerance test 


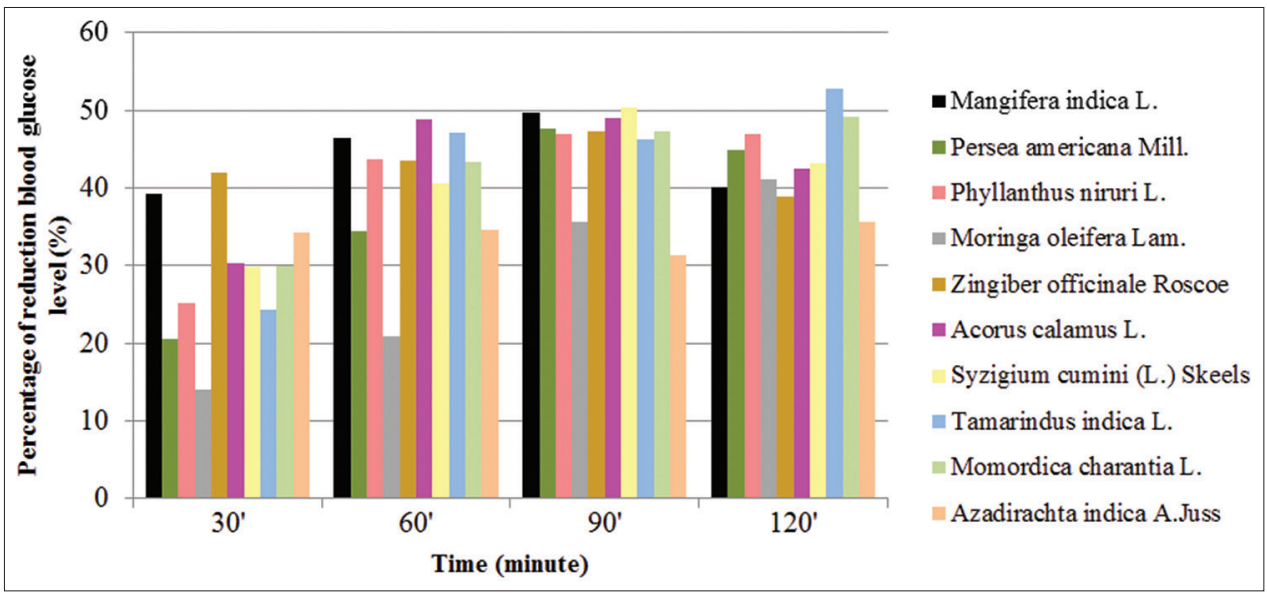

Fig. 2: Percentage of decrease blood glucose level (\%) of 10 medicinal plants extract tested that induced blood glucose level

that they still had hypoglycemic activity at that time. According to the blood glucose relative level, the percentage of reduction blood glucose level could be calculated with $\mathrm{Cr}$ (negative control) - $\mathrm{Cr}$ (test group)/ $\operatorname{Cr}$ (negative control) $\times 100 \%$.

As shown in Table 2 and Fig. 2, all tested extracts decreased blood glucose levels. Z. officinale Roscoe rhizome extract had the highest percentage of decrease blood glucose level at 30 minutes. After 60 minutes, the percentage of all tested extracts would increase. In addition, at 90 minutes, all extracts still had hypoglycemic activity, except $M$. oleifera Lam. leaves and $A$. indica A. Juss leaves.

An analysis of variance was conducted to find out differences of hypoglycemic activity each group, followed with Duncan method to test pairwise comparisons between average couples. The result showed that $M$. indica L. has the highest hypoglycemic activity, followed by Z. officinale Roscoe, A. calamus L., T. indica L., Momordica charantia L., S. cumini (L.) Skeels, P. niruri L., P. americana Mill., A. indica A. Juss, and M. oleifera Lam.

M. indica L. leaves have been confirmed to contain mangiferin (1,3,6,7-tetrahydroxyxanthone-C2-beta-D-glucoside, one of xanthone derivatives and C-glucosylxanthones) [20]. Mangiferin was widely distributed especially in the leaves and the bark in the Anacardiaceae and Gentianaceae families [21]. Mangiferin was one of the pharmacologically active compounds, which has been reported to have multiple biological effects and also antidiabetic effects [22-24]. Ethanolic extract of the leaves of $M$. indica L. leaves produced a significant hypoglycemic effect at a dose of $250 \mathrm{mg} / \mathrm{kg}$, both in normal and streptozotocin (STZ)induced diabetic animals. The stimulation of $\beta$-cells to release insulin was thought to be part of the mechanism of action [25]. The effect of the aqueous extract of the leaves of M. indica L. leaves on blood glucose level in normoglycemic, glucose-induced hyperglycemic, and STZ-induced diabetic rats indicate that the aqueous extract of the leaves of $M$. indica $\mathrm{L}$. possesses hypoglycemic activity. This action may be due to an intestinal reduction of the absorption of glucose [26]. The leaves of $M$. indica $\mathrm{L}$. used for antidiabetic properties using normoglycemic, glucose-induced hyperglycemia, and STZ-induced diabetic mice. The aqueous extract of the leaves of M. indica L. possesses hypoglycemic activity [27]. Oral glucose tolerance test in rats mangiferin $(10$ and $20 \mathrm{mg} / \mathrm{kg}$, i.p.) indicate potent antidiabetic without causing hypoglycemia; mangiferin would then offer a greater therapeutic benefit for the management of DM and diabetic complications associated with abnormalities in lipid profiles [27]. The results from this research suggest that $M$. indica $\mathrm{L}$. leaves can possibly help in the treatment of diabetes.

\section{CONCLUSION}

$M$. indica $\mathrm{L}$. leaves were considered to have the highest hypoglycemic activity in glucose-induced mice, followed by Z. officinale Roscoe rhizome, $A$. calamus L. rhizome, T. indica L. seed., M. charantia L. fruit.,
Table 2: Percentage of decreased blood glucose level (\%) at 30 minutes ( $t=30), 60$ minutes $(t=60), 90$ minutes $(t=90)$, and 120 minutes $(t=120)$ after administration of glucose

\begin{tabular}{lllll}
\hline \multirow{2}{*}{ Group } & \multicolumn{5}{l}{ Time (minute) } \\
\cline { 2 - 5 } & $\mathbf{3 0}$ & $\mathbf{6 0}$ & $\mathbf{9 0}$ & $\mathbf{1 2 0}$ \\
\hline Mangifera indica L. leaves & 39.29 & 46.36 & 49.75 & 40.15 \\
Persea Americana Mill. leaves & 20.53 & 34.45 & 47.61 & 44.82 \\
Phyllanthus niruri L. herb & 25.20 & 43.72 & 46.98 & 46.96 \\
Moringa oleifera Lam. leaves & 14.08 & 20.80 & 35.70 & 41.13 \\
Zingiber officinale Roscoe rhizome & 41.93 & 43.59 & 47.33 & 38.90 \\
Acorus calamus L. rhizome & 30.38 & 48.78 & 49.00 & 42.51 \\
Syzygium cumini (L.) Skeels leaves & 29.76 & 40.54 & 50.36 & 43.18 \\
Tamarindus indica L. seed & 24.36 & 47.10 & 46.25 & 52.83 \\
Momordica charantia L. fruit & 29.99 & 43.26 & 47.29 & 49.23 \\
Azadirachta indica A. Juss leaves & 34.29 & 34.56 & 31.42 & 35.68 \\
\hline
\end{tabular}

S. cumini (L.) skeels bark, P. niruri L. herb., P. americana Mill. leaves, and A. indica A. juss leaves.

\section{REFERENCES}

1. ADA (American Diabetes Association). Diagnosis and classification of diabetes melitus. Diabetes Care 2013;36:S67-74.

2. Dipiro JT, Talbert RL, Yee GC, Matzke G, Wells B, Posey LM. Pharmacotherapy: A Patophysiologic Approach. $8^{\text {th }}$ ed. New York: McGraw-Hill; 2011.

3. IDF (International Diabetes Federation). Indonesia; 2015. Available from: https://www.idf.org/membership/wp/indonesia.

4. WHO (World Health Organization). Prevention of Diabetes Mellitus. Geneva: WHO; 1994.

5. Jouad H, Haloui M, Rhiouani H, El Hilaly J, Eddouks M. Ethnobotanical survey of medicinal plants used for the treatment of diabetes, cardiac and renal diseases in the North centre region of Morocco (Fez-Boulemane). J Ethnopharmacol 2001;77(2-3):175-82.

6. Bappenas. Strategi Nasional Pengelolaan Keanekaragaman Hayati. Indonesia: Bappenas; 1993.

7. Esai PT. Indeks Tumbuh-Tumbuhan Obat. Indonesia: EISAI; 1986.

8. Sampoerno H. Pengembangan dan pemanfaatan tumbuhan obat Indonesia. Paper Presented at the National Seminar on Medicinal Plants from Indonesian Tropical Forest. Bogor, Indonesia. 28, April; 1999.

9. Zuhud EA, Aziz S, Ghulamahdi M, Andrawulan N, Darusman LK. Dukungan teknologi pengembangan obat asli Indonesia dari segi budaya, pelestarian dan pasca panen. Paper Presented at the Workshop on Agribusiness Development Based on Biopharmaca. Jakarta, Indonesia. Depatement Pertanian. 13-15 November; 2001

10. Sinha D, Dwivedi C, Dewangan MK, Yadav R, Rao SP, Chandrakar K, et al. Anti diabetic potential of herbal plants and polyherbal formulation. Int J Phytother Res 2014;4 Suppl 3:28-49.

11. Petchi RR, Parasuraman S, Vijaya C, Darwhekar G, Devika GS. Antidiabetic effect of kernel seeds extract of Mangifera indica (Anacardiaceae). Int J Pharm Bio Sci 2011;2 Suppl 1:385-93. 
12. Antia BS, Okokon JE, Okon JA. Hypoglycemic activity of aqueous leaf extract of Persea americana Mill. Indian J Pharmacol 2005;37 Suppl 5:325-6.

13. Okoli CO, Ibiam AF, Ezike AC, Akah PA, Okoye TC. Evaluation of antidiabetic potentials of Phyllanthus niruri in alloxan diabetic rats. Afr J Biotechnol 2009;9(2):248-59.

14. Jaiswal D, Rai PK, Kumar A, Mehta S, Watal G. Effect of Moringa oleifera Lam. Leaves aqueous extract therapy. J Ethnopharmacol 2009;123:392-6.

15. Bhandari U, Kanojia R, Pillai KK. Effect of ethanolic extract of Zingiber officinale on dyslipidaemia in diabetic rats. J Etnopharmacol 2005;97:227-30.

16. Prisilla DH, Balamurugan R, Shah R. Antidiabetic activity of methanol extract of Acorus calamus in STZ induced diabetic rats. Asian Pac J Trop Biomed 2012;21:941-6.

17. Ajit K, Choudhary BK, Bandyopadhyay NG. Comparative evaluation of hypoglycaemic activity of some Indian medicinal plants in alloxan diabeticrats. J Ethnopharmacol 2003;84:105-8.

18. Heidari Z, Sagheb AM, Shahraki M, Moudi B. A stereological study of effects of aqueous extract of Tamarindus indica seeds on pancreatic islets in streptozotocin - Induced diabetic rats. Pak J Pharm Sci 2010;23 Suppl 4:427-34.

19. Dholi SK, Raparla R, Mankala SK, Nagappan K. In vivo antudiabetic evaluation of neem leaf extract in alloxan induced Rats. J Appl Pharm
Sci 2011;1 Suppl 4:100-5

20. Desai PD, Ganguly AK, Govindachari TR, Joshi BS, Kamat VN, Manmade $\mathrm{AH}$, et al. Chemical investigation of some Indian plants: Part II. Indian J Chem 1996;4:457-549.

21. Yoshimi N, Matsunaga K, Katayama M, Yamada Y, Kuno T, Qiao Z, et al. The inhibitory effects of mangiferin, a naturally occuring glucosylxanthone, in bowel carcinogenesis of male F344 rats. Cancer Lett 2001;163:163-70.

22. Ichiki H, Miura T, Kubo M, Ishihara E, Komatsu Y, Tanigawa K, et al. New antidiabetic compounds, mangiferin and its glucoside. Biol Pharm Bull 1998;21:1389-90.

23. Miura T, Ichiki $H$, Hashimoto I, Iwamoto N, Kato M, Kubo M, et al. Antidiabetic activity of a xanthone compound, mangiferin. Phytomedicine 2001;8:85-7.

24. Muruganandan S, Scrinivasan K, Gupta S, Gupta PK, Lal J. Effect of mangiferin on hyperglycemia and atherogenicity in streptozotocin diabetic rats. J Ethnopharmacol 2005;97:497-501

25. Sharma SR, Dwivedi SK, Swarup D. Hypoglycemic potential of Mangifera indica leaves in rats. Int J Pharmacol 1997;35:130.

26. Aderibigbe AO, Emudianughe TS, Lawal BA. Antihyperglycaemic effect of Mangifera indica in rat. Phytother Res 1999;13:504-7.

27. Aderibigbe AO, Emudianughe TS, Lawal BA. Evaluation of the antidiabetic action of Mangifera indica in mice. Phytother Res $2001 ; 15(5): 456-8$. 